\title{
A REPLY TO CÉSPEDES' DEFENSE OF CAUSAL CONTRASTIVISM
}

\author{
Asbjørn STEGLich-PETERsen \\ Department of Philosophy and Intellectual History \\ Aarhus University \\ filasp@cas.au.dk
}

\begin{abstract}
SUMMARY: In a recent article in this journal, Esteban Céspedes (2015) seeks to defend the contrastive account of singular causation from my criticisms (SteglichPetersen 2012). Céspedes objects to my argument on three counts: (1) it is circular in presupposing a principle that it seeks to establish; (2) that same principle is false; and (3) even if the principle were true, it would not speak against the contrastive account. In this note I argue that all three objections are unconvincing.
\end{abstract}

KEY WORDS: contrastive account of causation, counterfactual conditional, general causation, singular causation, explanation

RESUMEN: En un artículo reciente en esta revista, Esteban Céspedes (2015) intenta defender a la teoría contrastiva de la causación singular contra mis críticas (SteglichPetersen 2012). Céspedes objeta a mi argumento de tres maneras: (1) es circular al presuponer un principio que pretende establecer; (2) el principio en cuestión es falso; y (3) incluso si fuera verdadero, no iría en contra de la teoría contrastiva. En esta nota argumento que ninguna de las tres objeciones es convincente.

PALABRAS CLAVE: teoría contrastiva de la causación, condicional contrafáctico, causación general, causación singular, explicación

\section{Against the Contrastive Account of Singular Causation}

According to the contrastive account, singular causation is not simply a binary relation between a cause and an effect, but a ternary or quaternary relation between a cause, an effect, and suitable contrasts to either or both of the cause and effect (e.g. Maslen 2004; Schaffer 2005; Northcott 2008). The account thus claims that all binary causal claims of the form "A caused B" are semantically incomplete in the absence of specifications of suitable contrasts to $\mathrm{A}$ and/or $\mathrm{B}$. Complete causal claims have the following form:

\section{1. $A$ (rather than $A^{*}$ ) caused $B$ (rather than $B^{*}$ )}

This radically simplifies the truth-conditions of causal claims, with the consequence that a number of puzzles and paradoxes in the theory of causation stand to be resolved. On the counterfactual elaboration of the contrastive account, contrastive causal statements like (1) are true if and only if, had $A^{*}$ happened instead of $A, B$ would not have 
happened (I will henceforth ignore effect-contrasts for simplicity). ${ }^{1}$ This makes causal claims much easier to evaluate, since one no longer has to determine what would in fact have happened, if $A$ had not occurred. All we have to determine is whether $B$ would have happened if some predetermined contrast $A^{*}$ had happened instead of $A$, whether or not $A^{*}$ would in fact have occurred, which is considerably less demanding.

My argument against the contrastive account has two parts, a negative and a positive, neither of which can be considered conclusive, but which together on balance reveals the binary account to be more plausible than the contrastive account. The negative part shows that the contrastive account is committed to denying certain implications of contrastive causal statements. The positive part develops a binary alternative to the contrastive semantics for contrastive causal statements that enjoys many of the same explanatory advantages claimed by the constrastive account, thus defusing a central argument in favor of contrastivism. Céspedes only considers the negative part of my argument, so that is what I shall focus on here as well.

The negative argument is, simply put, that if the contrastive account of singular causal claims were correct, it would not be relevant to the truth-value of causal claims such as " $A$ rather than $A$ * caused $B$ " what would have happened instead of $A$, if $A$ had not occurred; but it does matter what would have happened instead of the $A$; in particular, causal claims of that form imply that $A^{*}$ would have occurred, had $A$ not occurred; so, the contrastive account fails.

To motivate that this implication holds, I point out the intuitive contradiction between contrastive causal statements and explicit denials that the relevant contrast cause would have occurred, as in the following statement pairs:

2. Susan throwing a rock rather than walking away caused the window to shatter. If she hadn't thrown a rock, she wouldn't have walked away, but instead thrown a brick.

3. Susan stealing the bicycle rather than purchasing it caused her arrest. If she hadn't stolen the bicycle, she wouldn't have purchased it, but instead stolen the skis.

${ }^{1}$ For this particular version of the truth-conditions of singular contrastive causal statements, see Maslen 2004 and Northcott 2008. Other defenders seem committed to something like this account as well. For background on the counterfactual account, and comparison to other theories, see Steglich-Petersen 2010. 
I claim that in each of these statement pairs, the first statement intuitively contradicts the second, thus supporting my central claim.

\section{Céspedes' First Objection}

Céspedes' first objection (p. 96) starts from the correct observation that these intuitive judgments of incoherence could be right only if the following principle is true, where " $\square \rightarrow$ " stands for counterfactual implication:

4. For any events $A, A^{*}$ and $B$ : $\left(A\right.$ rather than $A^{*}$ caused $\left.B\right)$ entails (not- $A \square \rightarrow A^{*}$ )

According to Céspedes, this makes the argument circular: (4) is the very claim that my negative argument seeks to establish; but the intuitive judgments that (2) and (3) are internally inconsistent presuppose the truth of (4); so the argument presupposes what it wants to conclude. But it is not necessarily circular to infer a conclusion on the basis of a premise, the truth of which presupposes the truth of the conclusion. Otherwise it would not be possible to argue in a non-circular way for $q$ on the basis of $p$ whenever $p$ implies q. This requires, of course, that one's reasons for accepting the premise do not rely on prior acceptance of the conclusion. But that is not the case in my argument: our reason for deeming (2) and (3) internally inconsistent is that they intuitively strike us as such; this judgment does not rely prior acceptance of (4). Céspedes may of course deny the intuition. But that would not show the argument to be circular.

Compare with other standard arguments relying on intuitive judgments about cases. In Gettier's counterexamples to the account of knowledge as justified true belief, two scenarios are presented in which we judge the protagonist to have a justified true belief that $\mathrm{p}$, but nevertheless fail to know that $\mathrm{p}$. On that basis, we conclude that justified true belief is not sufficient for knowledge. Now, these intuitive judgments are correct only if justified true belief is not in fact sufficient for knowledge - exactly what the counterexamples sought to establish. So on reasoning parallel to that of Céspedes, it would be circular to conclude on the basis of these judgments that justified true belief is insufficient for knowledge. But of course, it isn't circular to conclude this. The intuitive judgments add independent support to the conclusion, even if these judgments are true only if the conclusion is true, and they, in that sense, "presuppose" the 
conclusion. The same is the case for my negative argument against the contrastive account.

\section{Céspedes'Second Objection}

After making the circularity objection, Céspedes moves on (p. 97) to argue directly against (4). He claims that contrastive causal claims only indicate what would have happened if some other alternative specified event had happened, and that they do not thereby imply anything as to whether that alternative would in fact have happened. $\mathrm{He}$ points out that this further information can sometimes be obtained from the conversational context, and provides some examples where this is the case. Such examples do not, of course, in themselves speak against (4). Nothing in my argument precludes that information about alternatives may also be obtained from the conversational context.

However, one of the examples, which I also discuss in my original paper (p. 130), is presented as a counterexample to (4). We are here to imagine that Susan is a kleptomaniac with a particular urge to steal large items. One day, she walks into a sporting goods store and steals a bicycle. Moments later, she is arrested. Given her particular kleptomaniac dispositions, Susan would have stolen some other large item if she hadn't stolen the bicycle, and would thus presumably still have been arrested. In my 2012, I argue that in this case, the binary causal claim that Susan stealing the bicycle caused her arrest is strictly speaking false, since it is not the case that Susan would have avoided arrest if she hadn't stolen the bicycle. Céspedes seems to accept this judgment (which of course doesn't preclude the truth of the very similar causal claim that Susan stealing the something caused her arrest). But Céspedes nevertheless claims that in this case, it is true that Susan stealing the bicycle rather than purchasing it caused her arrest - even if Susan would not in fact have purchased it if she hadn't stolen the bicycle, and would have been arrested if she hadn't stolen it. If Céspedes is right about this case, it would indeed be a counterexample to (4). But Céspedes does not provide any argument for this verdict, which goes directly against the intuition that (2) and (3) are internally inconsistent. More must therefore be said for this objection to be convincing. 


\section{Céspedes' Third Objection}

Céspedes' third objection (p. 98) is that even if it does matter to the evaluation of contrastive causal claims what would have happened instead of the cause, if the cause had not occurred, it doesn't follow from this that the contrastive account is false. If I understand him correctly, Céspedes' argument is simply to point out that there is a difference between claiming that the truth-value and the adequacy of contrastive causal claims depends on what happens instead of the cause. According to Céspedes, the contrastivist can accept that the "adequacy" of contrastive causal claims depends on what in fact would happen instead of the cause, while denying that the truthvalue depends on this. That may well be correct, depending on what one means by "adequacy". But that doesn't address my argument that the truth-value, and not merely the "adequacy" of causal claims such as " $A$ rather than $A$ * caused $B$ " depends on what would have happened instead of $A$, if $A$ had not occurred. As far as I can see, Céspedes' third argument does nothing to undermine that.

\section{Conclusion}

I conclude that Céspedes' defense of the contrastive account is unconvincing. On a more conciliatory note, what Céspedes' arguments reiterate is that my negative argument against the contrastive account cannot stand alone. It depends on certain intuitive judgments that Céspedes clearly doesn't share. That is why the positive part of my argument is needed as well, where I develop a binary alternative to the contrastive semantics for contrastive causal statements that enjoys many of the same explanatory advantages claimed by the constrastive account.

\section{REFERENCES}

Céspedes, Esteban, 2015, "A Defense of the Contrastive Theory of Causation”, Crítica. Revista Hispanoamericana de Filosofía, vol. 47, no. 140, pp. 93-99.

Maslen, Cei, 2004, "Causes, Contrasts, and the Nontransitivity of Causation", in Ned Hall, L.A. Paul and John Collins (eds.), Causation and Counterfactuals, MIT Press, Cambridge, Mass., pp. 341-357.

Northcott, Robert, 2008, "Causation and Contrast Classes", Philosophical Studies, vol. 139, no. 1 pp. 111-123.

Schaffer, Jonathan, 2005, "Contrastive Causation", Philosophical Review, vol. 114, no. 3, pp. 327-358. 
Steglich-Petersen, Asbjørn, 2012, "Against the Contrastive Account of Singular Causation", British Journal for the Philosophy of Science, vol. 63, no. 1, pp. 115-143.

— _ 2010, "Causation", in Roberto Poli and Johanna Seibt (eds.), Theory and Applications of Ontology: Philosophical Perspectives, Springer Verlag, pp. 83-104.

Received: June 6, 2016; accepted: June 21, 2016. 